\title{
Central serotonin receptors and delayed gastric emptying in non-ulcer dyspepsia
}

\author{
A Chua, J Keating, D Hamilton, P W N Keeling, T G Dinan
}

Abstract

Objective-To determine whether central serotonin receptors are involved in the pathophysiology of non-ulcer dyspepsia.

Design-Between subjects study of solid phase gastric emptying and prolactin response to buspirone challenge.

Subjects-12 patients fulfilling criteria for nonulcer dyspepsia and 12 age and sex matched controls.

Main outcome measures-Solid phase gastric emptying measured by scintigraphic assessment of the movement of a standard meal labelled with technetium-99m and indium-111; responsiveness of central serotonin $1 \mathrm{~A}$ receptors measured by the prolactin release following challenge with oral buspirone $60 \mathrm{mg}$.

Results-Solid phase gastric emptying was significantly delayed in the patients with non-ulcer dyspepsia $\left(t \frac{1}{2}=90.6\right.$ (SD 14.5) minutes in patients and $54.6(10.7)$ minutes in controls; $95 \%$ confidence interval 24.7 to 46.7 minutes, $p<0.001$ ). Prolactin release was significantly greater in patients compared with controls $(1272.7(1039.9) \mathrm{mU} / 1$ $v 292.9$ (136.1) $\mathrm{mU} / 1 ; 352.1$ to $1607.5 \mathrm{mU} / 1, \mathrm{p}<0.01)$. Gastric emptying and prolactin release were significantly correlated $(r=0.59, p=0.04)$ in the patients but not in the controls $(r=0 \cdot 23)$.

Conclusion-Central serotonin $1 \mathrm{~A}$ receptors may have a role in the pathophysiology of non-ulcer dyspepsia of the dysmotility subtype.

\section{Introduction}

Symptoms of postprandial fullness or bloating, early satiety, excessive flatulence, upper abdominal pain, and nausea are commonplace both in primary care and in gastroenterology clinics. ${ }^{12}$ These symptoms, however, are attributable to organic disease in only a minority of cases. The substantial group of patients who have persistent and occasionally disabling gastric symptoms without organic disease are classified as having functional dyspepsia or non-ulcer dyspepsia. ${ }^{13-6}$

Non-ulcer dyspepsia is a heterogeneous condition Gastroenterology, Nuclear Medicine, and Psychiatry, Trinity College Medical

School, St James's

Hospital, Dublin 8,

Republic of Ireland

A Chua, research registrar in gastroenterology

$\mathrm{J}$ Keating, senior registrar in gastroenterology

D Hamilton, medical physicist

P W N Keeling, consultant gastroenterologist

T G Dinan, consultant psychiatrist

Correspondence to: Dr Dinan.

BMF 1992;305:280-2 serotonin receptors were supersensitive in a sample of patients with non-ulcer dyspepsia. ${ }^{10}$

The abnormality in gastric emptying seen in patients with functional dyspepsia could therefore be due to a defect affecting the brain-gut axis, more specifically $\overbrace{}^{\circ}$ the central serotonergic system.

The neuroendocrine axis provides an acceptable means of studying the functioning of central serotonin $\vec{\omega}$ receptors. The release of prolactin from the anterior pituitary is under the inhibitory control of dopamine and the stimulatory control of serotonin." When hypothalamic receptors are stimulated by an appro- or priate serotonin agonist serum prolactin concentration increases. Buspirone, an azaspirodecanedione, $\stackrel{\infty}{\infty}$ stimulates central serotonin $1 \mathrm{~A}$ receptors and releases $i$ prolactin in a dose related manner. ${ }^{1012}$ The extent of ${ }^{\infty}$ release is a good measure of the sensitivity of central 윽 serotonin 1A receptors. The aim of our study was to examine this sensitivity in patients with non-ulcer dyspepsia in whom solid phase gastric emptying was measured. We hypothesised that patients with the os greatest serotonin mediated prolactin release would $\vec{\bullet}$ also show the greatest delay in solid phase gastric 6 emptying.

\section{Patients and methods}

We studied 12 dyspeptic patients, six men and six women, with a mean age of $30(\mathrm{SD} \mathrm{6.4})$ years. They were compared with 12 healthy subjects matched for $\overline{\overline{0}}$ age and sex. The mean age of this sample was $31(6.9)$ years. To be included in the study patients must have had at least four of the following symptoms for at least three months: early satiety, upper abdominal pain, postprandial bloating or fullness, excessive flatulence, borborygmus, and nausea or vomiting, or both. They all had normal results on physical examination. Endo- 3 scopic examination, 24 hour ambulatory $\mathrm{pH}$ monitor- $\delta$ ing, and abdominal ultrasonography gave normal $§$ results, and gastric biopsy specimens were negative for 응 helicobacters in all the patients. Likewise, patients had no evidence of endocrine disorder, connective tissue $\circ$ disease, somatic myopathy, or excessive alcohol $\frac{7}{2}$ intake. All were non-smokers and none were taking drugs likely to alter serotonin metabolism or affect $\tilde{O}$ gastric motility. All patients and subjects were $\underset{\omega}{N}$ screened by a consultant psychiatrist and none had 0 evidence of formal psychiatric illness.

Gastric emptying was determined by scintigraphic assessment of the movement of a standard breakfast $\stackrel{\mathcal{P}}{+}$ consisting of $50 \mathrm{~g}$ of cooked egg whites containing tin $\square$ colloid labelled with technetium- $99 \mathrm{~m}, 100 \mathrm{~g}$ of lightly buttered toast, and $100 \mathrm{~g}$ of orange juice containing $\cong$ diethylenetriaminepenta-acetic acid labelled with $\odot$ indium-111 $(0.5 \mu \mathrm{Bq})$. The test meal was consumed $\bar{\sigma}$ within five minutes and the point of completion of the meal taken as time zero. Data were acquired for each radionucleotide in both the anterior and posterior orientation at five minute intervals for 30 minutes, at 10 minute intervals for 50 minutes, and at 20 minute intervals for $\mathbf{4 0}$ minutes. The scintigraphic data were corrected for cross talk variation in acquisition time and attenuation; for attenuation we used a geometric 


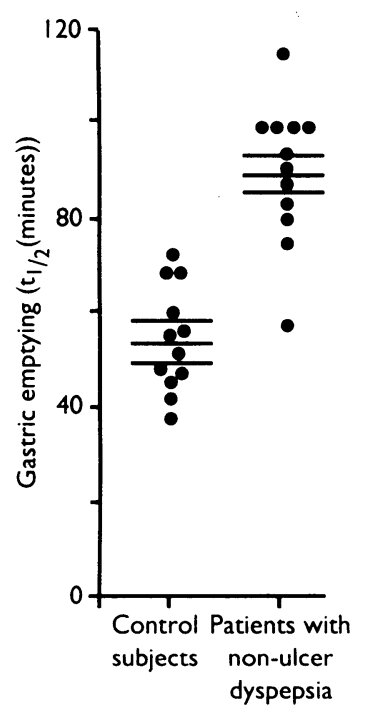

FIG 1-Solid phase gastric emptying rates in patients with non-ulcer dyspepsia and in healthy controls. Horizontal bars show mean $(S E)$ values

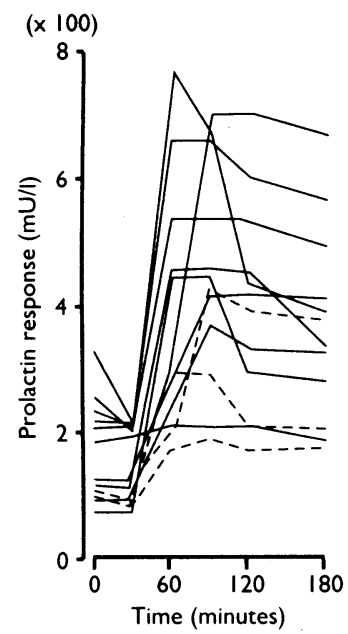

FIG 2-Prolactin response to buspirone $60 \mathrm{mg}$ in healthy subjects



FIG 3-Prolactin response to buspirone $60 \mathrm{mg}$ in patients with non-ulcer dyspepsia mean of anterior and posterior orientation data. The counts obtained were normalised to the start of the study and emptying curves were plotted from the serial data acquired. Gastric half emptying times $(t 1 / 2)$ were calculated from these curves. The reproducibility of this isotope test has previously been reported. ${ }^{13}$

\section{NEUROENDOCRINE CHALLENGE TEST}

A neuroendocrine challenge test using buspirone as a stimulator of central serotonin $1 \mathrm{~A}$ receptors was performed one week after scintigraphic assessment. Serum prolactin concentrations were measured with an immunofluorescence technique (LKB method). The sensitivity of the assay was $1.5 \mathrm{mU} / 1(0.04 \mathrm{ng} / \mathrm{ml})$. The intra-assay coefficients of variation were $2 \cdot 0 \%$, $2.6 \%$, and $3.3 \%$ at serum prolactin concentrations of $110 \mathrm{mU} / 1,760 \mathrm{mU} / 1$, and $2975 \mathrm{mU} / 1$. The corresponding interassay coefficients of variation were $5 \cdot 7 \%$, $3 \cdot 4 \%$, and $6 \cdot 2 \%$. In a previous study eight male subjects were tested on three separate occasions and the prolactin response to buspirone was consistently reproducible while the response in six female subjects was reproducible when the test was conducted at the same point in the menstrual cycle. ${ }^{12}$ All female subjects in this current study were tested in the follicular phase of the menstrual cycle.

Subjects presented at 0830 after having fasted from midnight. Venous access was obtained with a cannula in a forearm cubital vein. After two basal blood samples buspirone $60 \mathrm{mg}$ was given orally at 0900 . A further five samples were then taken at $30,60,90,120$, and 180 minutes.

A serum sample for buspirone estimation was taken at 90 minutes after administration in all subjects to ensure that any differences that might be detected in prolactin response were not simply due to different blood concentrations of buspirone, perhaps as a result of differences in gastric emptying.

Paired Student $t$ tests were used to compare the gastric emptying rates and serum prolactin response between patients and controls. A repeated measures two way analysis of variance examined changes in prolactin levels over time in the two groups. Pearson product-moment correlation coefficients were used to examine the relation between gastric emptying rates and prolactin responses. All data was analysed by means of Statgraphics. ${ }^{14}$

\section{Results}

Solid phase gastric emptying ( $\left.t^{1 / 2}\right)$ measured from time of ingestion differed markedly in both groups, patients with non-ulcer dyspepsia having a mean of $90 \cdot 6(14.5)$ minutes compared with $54 \cdot 6(10 \cdot 7)$ minutes in the healthy controls $(t=6.8, \mathrm{df}=23, \mathrm{p}<0.001 ; 95 \%$ confidence interval $24 \cdot 7$ to $46 \cdot 7$ ) (fig 1 ). There was no difference in liquid phase emptying $(t 1 / 2)$, patients having a mean of 32.4 (SE $2 \cdot 8$ ) minutes and healthy subjects $32 \cdot 3(3 \cdot 1)$ minutes.

Prolactin concentrations rose in response to buspirone in all subjects (figs 2 and 3). Measuring prolactin response as the mean baseline prolactin concentration subtracted from the maximum prolactin concentration after buspirone, we obtained a mean of $1272.7(1039.9) \mathrm{mU} / \mathrm{l}$ in the patients and 292.9 $(136 \cdot 1) \mathrm{mU} / 1$ in the healthy controls $(t=3 \cdot 2, \mathrm{df}=23$, $\mathrm{p}<0.01 ; 352 \cdot 1$ to $1607 \cdot 5)$. A two way analysis of variance with a repeated measures design examining alterations in prolactin over time in the two groups yielded a significant group $\times$ time interaction $(F=2 \cdot 90$, $\mathrm{df}=6,153, \mathrm{p}<0 \cdot 01)$. A post-hoc Scheffe test was significant at 90 minutes $(\mathrm{p}<0.01)$ and 120 minutes $(\mathrm{p}<0.05)$. Prolactin concentration 90 minutes after buspirone therefore provided the best discrimination between the two groups.
The mean buspirone concentration at 90 minutes in the non-ulcer dyspepsia group was $25.4(12.5) \mu \mathrm{g} / \mathrm{l}$ and in the healthy controls $23.8(16 \cdot 6) \mu \mathrm{g} / \mathrm{l}(t=1 \cdot 2$, $\mathrm{df}=23$, NS; $19 \cdot 6$ to $30 \cdot 8$ ). Both patients and controls therefore absorbed buspirone in a similar manner. Gastric emptying rates and prolactin response were correlated for both groups. No relation was established in the controls $(r=0.23, \mathrm{NS})$. In the patients $r=0.59$, $\mathrm{p}=0.04$.

\section{Discussion}

Though non-ulcer dyspepsia is a heterogeneous disorder, we carefully selected our patient group as having clusters of symptoms (nausea or vomiting, or both; early satiety; postprandial bloating or a feeling of distension, or both; and excessive belching) suggestive of an underlying motility disturbance. ${ }^{2}$ This subgroup of dyspeptic patients, who have no evidence of infection with Helicobacter pylori, make up approximately $35 \%$ of our patients with non-ulcer dyspepsia. ${ }^{15}$ Furthermore, none of our patients fulfilled the criteria for diagnosing true irritable bowel syndrome. ${ }^{16}$

The results confirm the findings from other centres that non-ulcer dyspepsia may be related to a motor disorder of the upper gastrointestinal $\operatorname{tract}^{717}$ because patients showed significantly delayed gastric emptying compared with healthy controls. You et al described the presence of tachyarrhythmia associated with retropropagation of pacesetter potentials, arising from an ectopic focus in the stomach antrum of a patient with nausea, vomiting, abdominal bloating, and pain. ${ }^{18}$ An ectopic gastric pacesetter could easily result in abnormal gastric emptying. Our findings suggest that the motor disturbance may be generated by malfunctioning central receptors of the serotonin type.

Patients with the postviral fatigue syndrome often present with symptoms of non-ulcer dyspepsia, and we have reported similar endocrine responses in such subjects. ${ }^{18 a}$ Raised intracranial pressure may also cause gastrointestinal symptoms. Moreover, Wood et al published a case report of a brain stem tumour presenting as an upper gut motility disorder. ${ }^{19}$ The upper gut can be modulated by brain stem nuclei ${ }^{20}$ situated both in the vagal motor complex (dorsal motor nucleus of the vagus ${ }^{21}$ and nucleus ambiguus ${ }^{22}$ ) and in the autonomic nuclei of the medullary reticular formation. The nuclei of the medullary reticular formation provide serotoninergic and noradrenergic inhibitory modulation of thoracolumbar sympathetic and parasympathetic outflow. ${ }^{2324}$ Abnormalities of the autonomic control of the gut, such as diabetic autonomic neuropathy ${ }^{25}$ and other autonomic system degeneration, ${ }^{26}$ may result in gastrointestinal motility disturbances. Although disorders of autonomic supply may give rise to dyspeptic symptoms ${ }^{25-27}$ patients with functional dyspepsia consistently fail to show any gross autonomic disturbances or brain stem disorders. Likewise, none of our patients showed any evidence of disordered autonomic function and no clinical evidence of raised intracranial pressure.

\section{ACTIONS OF SEROTONIN}

Serotonin is a monoamine that acts as both a peripheral transmitter in the gut ${ }^{28}$ and a central transmitter in the brain..$^{29}$ It has an important role in regulating peristalsis and intestinal tone. ${ }^{3031}$ Hyperserotoninaemia - for example, in the carcinoid syndrome-may present with nausea, vomiting, and colicky abdominal pain. ${ }^{32}$ Most patients with non-ulcer dyspepsia, however, are not hyperserotoninaemic. Our current findings lend further support to our preliminary data showing central serotoninergic supersensitivity in non-ulcer dyspepsia. ${ }^{10}$ The anxiolytic buspirone was used in this study to stimulate 
such central serotonin receptors. Recent work in our department (unpublished) and that of Coccaro et al supports the view that buspirone produces its prolactin response, at least partly, by stimulating serotonin $1 \mathrm{~A}$ receptors, probably in the hypothalamus. ${ }^{33}$ Its effects can be blocked by the antagonist methysergide and by pindolol, which in terms of its effect on serotonin metabolism binds only to $1 \mathrm{~A}$ receptors. These recent data cast considerable doubt on the view that buspirone may be working through dopamine receptors, suggesting rather that it affects serotonin $1 \mathrm{~A}$ receptors. The buspirone-prolactin data could be used to suggest that patients with non-ulcer dyspepsia have a primary pituitary dysfunction affecting the lactotrophs. This is unlikely because the stimulation and inhibition of prolactin by other probes such as fenfluramine and bromocriptine are normal in non-ulcer dyspepsia (unpublished data).

Intravenous injection of serotonin in dogs modulates gastric emptying ${ }^{31}$; furthermore, Rowland and Carlton showed that gastric emptying can be inhibited by injecting fenfluramine into the cerebral ventricles of rats. ${ }^{8}$ Fenfluramine is a potent anorectic drug and has been used clinically to control appetite. Its major behavioural effect is to reduce meal size and prolong the duration of satiety after a meal. ${ }^{12}{ }^{34}$ The primary neuronal effects of fenfluramine include release of serotonin from nerve terminals and inhibition of reuptake. ${ }^{35}$ These and other data have been used to support the theory that increased central serotoninergic activity suppresses appetite. ${ }^{34-36}$ Interestingly, all the patients in our study group complained of early satiety as one of their major symptoms.

\section{CONCLUSIONS}

The limitation of our current study is its small sample size. None the less, the fact that gastric emptying rates and endocrine responses were so highly correlated in the dyspeptic patients is of considerable interest. Further studies are under way to see whether altering the activity of central serotonin receptors changes rates of gastric emptying. The fact that a similar relation was not established in our healthy controls probably indicates that numerous factors control gastric emptying in normal circumstances but that in non-ulcer dyspepsia a pathophysiological process affecting serotonin $1 \mathrm{~A}$ receptors results in the predominance of these receptors and disturbs a homoeostatic balance.

Our results show that patients with non-ulcer dyspepsia with delayed gastric emptying have significantly greater responses to buspirone than do healthy controls. The probable central neurochemical dysfunction of hypersensitive serotonin receptors could account for the delayed gastric emptying observed in functional dyspepsia. Furthermore, abnormalities in gastric emptying may result in the symptom complex seen in non-ulcer dyspepsia. These results provide further evidence for the view that non-ulcer dyspepsia is not a functional disorder but characterised by hypersensitive central serotonin receptors resulting in abnormalities in gastric motility.

1 Tibbin G. Introduction to the epidemiology of dyspepsia. Scand f Gastroenterol 1985;20(suppl 109):29-33.

2 Colin-Jones DG. Management of dyspepsia: report of a working party. Lancet 1988;i:576-9.
3 Thompson WG. Non-ulcer dyspepsia. Can Med Assoc f 1984;130:565-9.

4 Talley NJ, Piper DW. The association between non-ulcer dyspepsia and other gastrointestinal disorders. Scand J Gastroenterol 1985;20:896-900.

5 Adami HO, Agenas I, Gustavsson S, Loof L, Nyberg A, Nyren O, Tyllstrum J. The clinical diagnosis of "gastritis." Aspects of demographic epidemiology and health care consumption based on a nationwide sample survey. Scand f Gastroenterol 1984;19:216-9.

6 Harvey RF, Salih SY, Read AE. Organic and functional disorders in 2000 gastroenterology outpatients. Lancet 1983;i:632-4.

7 Malagelada JR, Stanghellini V. Manometric evaluation of functional upper gut symptoms. Gastroenterology 1985;88:1223-31.

8 Rowland N, Carlton J. Inhibition of gastric emptying by peripheral and central fenfluramine in rats: correlation with anorexia. L Life Sci 1984;34:2495-9.

9 Silverstone T, Turner P. Drug treatment in psychiatry. London: Routledge and Kegan Paul, 1988.

10 Dinan TG, Yatham LN, Barry S, Chua A, Keeling PWN. Serotonin supersensitivity: the pathophysiologic basis of non-ulcer dyspepsia? Scand f Gastroenterol 1990;25:541-4.

11 Checkley SA. Neuroendocrine tests of monoamine function in man; a review of basic theory and its application to the study of depressive illness. of basic theory and its applic
Psychol Med 1980;10:35-53.

12 Dinan TG, Barry S, Yatham L, Mobayed M, O'Hanlon M. The reproducibility of the prolactin response to buspirone: relationship to the menstrual cycle. Int Clin Psychopharmacol 1989;5:119-23.

13 Collins PJ, Horowitz M, Cook DJ, Harding PE, Shearman DJC. Gastric emptying in normal subjects - a reproducible technique using a single scintillation camera and computer system. Gut 1983;24:1117-25.

14 Statistical Graphics Corporation. Statgraphics 1988. New York: Statistical Graphics Corporation, 1988

15 Chua A, Kennedy NP, Hamilton D, Keating JJ, Keeling PWN. Dysmotility type non-ulcer dyspepsia is negatively associated with campylobacter-like organisms. Gut 1988;29:A1437.

16 Manning AP, Thompson DG, Heaton KW, Mornis AF. Towards positive diagnosis of the irritable bowel. $B M \mathcal{Y}$ 1978;ii:653-6.

17 Camilleri M, Malagelda JR, Kao PC, Zinsmeister AR. Gastric and autonom response to stress in functional dyspepsia. Dig Dis Sci 1986;31:1169-77.

18 You CH, Chey WY, Lee KY, Menguy R, Bortoff A. Gastric and small intestinal myoelectric dysrrhythmia associated with chronic intractable nausea and vomiting. Ann Intern Med 1981;95:449-51.

18a Bakheit AMO, Behan PO, Dinan TG, Gray CE, O'Keane V. Possible upregulation of hypothalamic 5-hydroxytryptamine receptors in patients with postviral fatigue syndrome. $B M F$ 1992;304:1010-2

19 Wood JR, Camilleri M, Low PA, Malagelada JR. Brainstem tumor presenting as an upper gut motility disorder. Gastroenterology 1985;89:1411-4.

20 Eliasson S. Activation of gastric motility from the brain stem to the cat. Acta Physiol Scand 1953;30:199-214.

21 Kalia M, Mesulam MM. Brain stem projections of sensory and motor components of the vagus complex in the cat. I. Laryngeal, tracheobronchial, pulmonary, cardiac and gastrointestinal branches. Comparative Neurology 1980;193:467-508.

22 Pagini FD, Norman WP, Kasbekar DK, Gillis RA. Effects of stimulation of nucleus ambiguus complex on gastroduodenal function. Am $\mathcal{f}$ Physiol 1984;246:G253-62.

23 Coote JH, MacLeod VH. The influence of bulbospinal monoaminergic pathways

24 Loewy AD. Descending pathways to sympathetic and parasympathetic preganglionic neurons. $\mathcal{F}$ Auton Nerv Syst 1981;3:265-75.

25 Camilleri $M$, Malagelada JR. Abnormal intestinal motility in diabetics with the gastroparesis syndrome. Eur $\mathcal{Y}$ Clin Invest 1984;14:420-7.

26 Camilleri M, Malagelada JR, Stanghellini V, Realey RD, Sheps SG. Gastrointestinal motility disturbances in patients with orthostatic hypotension. Gastroenterology 1985;88:1852-9.

27 Khurara RK, Nelson E, Azzarelli B, Gacia JH. Shy-Drager syndrome: diagnosis and treatment of cholinergic dysfunction. Neurology 1980;30: $805-9$.

28 Gershon MD, Erde SM. The nervous system of the gut. Gastroenterolog 1981;80:1571-94.

29 Van Praag HM. Central monoamine metabolism in depression: serotonin and related compounds. Compr Psychiatry 1980;21:30-43.

30 Gilman AG, Goodman LS, Gilman A. The pharmacological basis of therapeutics. London: Baillière Tindall, 1980.

31 Hopkinson GB, Hinsdale S, Jaffe BM. Contraction of canine stomach and small bowel by intravenous administration of serotonin. A physiologic response? Scand f Gastroenterol 1989;24:923-32.

32 Harrison RJ. Textbook of internal medicine. London: Hodder and Stoughton, 1986.

33 Coccaro EF, Gabriel S, Mahon T, Macaulso J, Siever LJ. Preliminary evidence of a serotonin component to the prolactin response to buspirone challenge in humans. Arch Gen Psychiatry 1990;47:594-5.

34 Blundell JE. In: Wurtan RJ, Wurtman JJ, eds. Nutrition and the brain. Vol 6. New York: Raven, 1983:163-221.

35 Duhault J, Beregi L, Roman F. Substituted phenethylamines and anorexia. Progress in Neuro-Psychopharmacology 1980;4:341-9.

36 Davies RF, Rossi J, Panksepp J, Bean NJ, Zolovick AJ. Fenfluramin anorexia: a peripheral locus of action. Physiol Behav 1983;30:723-30.

(Accepted 22 May 1992) 